\title{
Optimization of the choice of molecular markers for identification of commercially used rice varieties in India using rapid DNA extraction protocol
}

\author{
Pravas Ranjan Kole ${ }^{1 *}$, Rajeev Singh Rana $^{2}$ and Kangila Venkataramana Bhat ${ }^{1}$ \\ ${ }^{1}$ Division of Genomic Resources, National Bureau of Plant Genetic Resources, Pusa Campus, New Delhi-110012, \\ INDIA \\ ${ }^{2}$ Crop Improvement Division, Central Research Institute for Jute \& Allied Fibres (ICAR), Barrackpore, Kolkata-700120, \\ INDIA \\ *Corresponding author. E-mail: prkole1979@gmail.com
}

Received: October 13, 2015; Revised received: March 17, 2016; Accepted: June 5, 2016

\begin{abstract}
The present investigating aimed at the development of molecular marker for cultivar identification and genetic purity assessment. A total of four SSR markers and six SRAP primer were developed for the identification of sixteen different commercial varieties of rice. Traditional practice like grow-out-test based on morphological traits is time consuming and sometimes environmentally influenced. After development of molecular marker, it is using as an alternative to grow -out -test because of its rapid, accurate detection. We have assessed the potential of simple sequence repeat and sequence-related amplified polymorphism markers in distinguishing rice varieties and four simple sequence repeat markers namely CT-14, CT-25 CT XY-1 and ATC-3 and six sequence-related amplified polymorphism markers primers could be clearly distinguished sixteen commercially cultivar rice varieties. In addition to single markers, it's better to try with marker combinations, which were amenable for PCR and capable of distinguishing the varieties. Larger differences for each crop were found between cultivers from different seed companies than within the same company. These DNA markers can provide an easier and faster reliable genetic identification of rice cultivars.
\end{abstract}

Keywords: Molecular marker, Oryza sativa, Rice, Simple sequence repeat, Sequence-related amplified polymorphism

\section{INTRODUCTION}

Rice (Oryza sativa L.) is one of the world's most important food crops, providing food for more than one third of the world's population. It is no longer a luxury food but has become the cereal that constitutes a major source of calories for the urban and the rural populations. Rice is grown in wide range of environments worldwide, even on a steep hill or mountain. Most of the world's rice is grown and consumed in Asia, which constitutes more than half of the global population. India is one of the Asian countries which had suitable agro-climatic conditions for rice growing. Approximately $11 \%$ of the world's arable land is planted annually to rice, and it ranks next to wheat. The world's rice production has doubled during last 25 years, largely due to the use of improved technology such as high yielding varieties and better crop management practices. Further scope of crop improvement depends on the conserved use of genetic variability and diversity in plant breeding programmes and use of new biotechnological tools (Chakravarthi and Naravaneni, 2006). Assessment of seed purity is one of the most important quality control components in hybrid seed production. Traditionally, it has been the practice to carry out a grow-out test (GOT), based on morphologi- cal traits, for assessment of purity of seeds. GOT takes one full growing season for completion, space demanding. It's often does not allow the unequivocal identification of genotypes. In the earlier reports, the use of Simple Sequence Repeat (SSR) and Sequence Tagged Site (STS) markers for rapid assessment of hybrid and parental line seed purity, as an alternative to GOT (Yashitola et al., 2002; Yashitola et al., 2004). Subsequently, Nandakumar et al. (2004) also showed the utility of SSR markers for fingerprinting rice hybrids. Dan et al. (2009) used Sequence-related Amplified Polymorphism (SRAP) to identify the hybrids and progeny of Zoysa crosses. Jing et al. (2012) provide a scientific basis for hybrid identification of switchgrass using SRAP and SSR marker. All these studies involved a limited of markers $(<12)$ and the assessment of genetic purity was based on single marker and single seed or seedling based analysis. For accurate detection of impurities in seed lots, it is essential to identify a set of informative markers which can clearly distinguish the parental lines and amplify specific or unique allele combinations in the hybrids, not present in any other rice line. Moreover, the assay should preferably be based on analysis of bulked samples rather than single seed assays so as to bring down the cost of the assay (Sundaram et al., 2008.). The aim of the present 
study was to develop gene markers for cultivar identification and DNA fingerprinting, we have characterized 16 commercially use rice varieties using 20 uniformly distributed hyper polymorphic rice SSR markers and 10 SRAP markers and utilized them in varietal seed purity assessments.

\section{MATERIALS AND METHODS}

Sixteen variety of rice cultivars were collected form National Seed Corporation, New Delhi (Table 1). Genomic DNA was extracted using simple and rapid method for PCR analysis by Edwards et al. (1991) with slight modification. Fifteen seeds from each cultivar were kept in towel paper for germination inside a temperature controlled incubator. The temperature was set on $30-32^{0}$ C. After $7-10$ days germinated seeds were takeout. The plant tissue $(100-200 \mathrm{mg})$ were cut into small pieces and place into a Mortar and Pestle. Add three times extraction buffer (cTAB) and grind it till a semisolid pest was seen. Extraction buffer was prepared with $10 \% \mathrm{CTAB}, 1 \mathrm{M}$ Tris buffer, $0.5 \mathrm{M}$ EDTA beta-mercaptoethanol and distilled water. Keep it at pre-wormed water bath for $10-20 \mathrm{~min}$ at $65^{\circ} \mathrm{C}$. After taking out from water bath leave it for some time to cool at room temperature. Add equal volume of chloroform into the tube. Mix in a roto mix for $20 \mathrm{~min}$ followed by centrifuge at $13000 \mathrm{rpm}$ for 10 minutes. Take out the aqueous layer in fresh eppendorf tube and add equal volume of Isopropanol and leave it for 30 min. Centrifuge at $13000 \mathrm{rpm}$ for $10 \mathrm{~min}$ to get the DNA pallet. Decant the supernatant without disturbing the pallet followed by washing with $70 \%$ ethyl alcohol. Finally air dried the pallet and dissolved the pallet with 10:1 TE buffer $(100 \mu \mathrm{l})$. To get more concentration dissolved the pallet 50-80 $\mu \mathrm{l} \mathrm{TE}$. The quality and concentration of extracted DNA were estimated by using a UV-Vis spectrophotometer (Nano drop, Thermo Fisher Scientific) at 260/280nm.

SSR amplification: DNA samples (40 ng) were amplified in 10-_1 reaction volumes containing $1 \mathrm{X}$ PCR buffer [10 mM Tris-HCl (pH 8.3), $50 \mathrm{mM} \mathrm{KCl,} 1.5$ $\mathrm{mM} \mathrm{MgCl} 2,0.01 \%$ (v/v) gelatin] (Bangalore Genei, India), $0.2 \mathrm{mM}$ of each dNTPs (Bangalore Genei, India), $10 \mathrm{pmol}$ of each primer and $1 \mathrm{U}$ of Taq polymerase (Bangalore Genei, India). PCR was carried out in a Thermal cycler (BIOER Xp Cycler, China). The basic PCR profile was $5 \mathrm{~min}$ at $94^{\circ} \mathrm{C}, 35$ cycles of 1 $\min$ at $94^{\circ} \mathrm{C}, 1 \mathrm{~min}$ at respective annealing temperature, $1 \mathrm{~min}$ at $72^{\circ} \mathrm{C}$ and $5 \mathrm{~min}$ at $72^{\circ} \mathrm{C}$ for final extension. The amplicons were resolved on $3 \%$ agarose gels, stained with ethidium bromide and visualized under UV as per the procedure described in Sambrook and Russell (2001) in a gel documentation system (Minilumi Gel Documentation System, Sigma-SVI) and impurities were identified based on deviations in expected amplification pattern. The sizes of the amplified fragments ere estimated with the help of Alphaease software utility of the gel documentation sys- tem using $1 \mathrm{~kb}$ DNA ladders (MBI Fermentas, Lithuania) as the size standards. If a certain allele with respect to a particular SSR marker was observed uniquely in just one of the rice genotypes under study and absent in all the other rice genotypes, it was considered to be specific for that genotype and such SSR markers were categorized as informative SSR markers. SRAP amplification: SRAP analysis was conducted according to previously established protocols (Li and Quiros 2001). In this assay, 30 different primer combinations were employed using six forward primers and six reverse primers combined randomly (Table 3). Firstly, SRAP primer combinations were screened. After screening under the optimized condition, primer combinations, generated strong and clear amplified bands, were selected for further investigations. Polymerase chain reaction was performed in $20 \mu \mathrm{L}$ reaction mixture containing $1 \times$ buffer, $2.0 \mathrm{mM} \mathrm{MgCl} 2,0.2 \mathrm{mM}$ dNTPs, $1 \mathrm{U}$ Taq DNA polymerase, $0.5 \mu \mathrm{M}$ primers, 50 ng DNA templates. Amplifications were carried out in a DNA thermal cycler (BIOER Xp Cycler) with an initial step at $94^{\circ} \mathrm{C}$ for $5 \mathrm{~min}$, and five cycles of $1 \mathrm{~min}$ at $94^{\circ} \mathrm{C}, 1 \mathrm{~min}$ at $35^{\circ} \mathrm{C}$, and $1.5 \mathrm{~min}$ at $72^{\circ} \mathrm{C}$. The following 35 cycles consisted of $94^{\circ} \mathrm{C}$ for $1 \mathrm{~min}, 50^{\circ} \mathrm{C}$ for $1 \mathrm{~min}$, and $72^{\circ} \mathrm{C}$ for $1 \mathrm{~min}$, with a final extension at $72^{\circ} \mathrm{C}$ for $10 \mathrm{~min}$. The PCR reactions were repeated twice for each primer pair to ensure reproducibility. Amplified products were separated on $1.5 \%$ agarose gels in $1 \times$ TAE buffer using DNA marker as molecular weight marker and visualized with ethidium bromide staining.

\section{RESULTS AND DISCUSSION}

Germplasm characterization, diversity studies and seed purity assays, DNA fingerprinting approaches based on polymerase chain reaction have become methods of choice. A variety of DNA markers are now available for fingerprinting cultivars and for marker assisted selection. Of these, SSRs are the preferred ones for rice due to their abundance, co-dominant nature and their distribution throughout the genome and userfriendly nature (Mc Couch et al., 2002). For the clear and stable amplification pattern SRAP marker is also effective for the authenticity, identification and genetic analysis (Dan et al., 2009). The present study, we have assessed the potential of SSR and SRAP markers in distinguishing rice varieties and utilized 'informative' SSR and SRAP markers for testing purity of seeds. A set of twenty SSRs primer used for the present study. Selection was made from the literature and synthesized them on the basis of their amplification and banding pattern. Out of twenty SSRs primers four markers gave amplification of specific and unique alleles (Fig. 1) among the varieties. Four markers namely CT-14, CT25 CT XY-1 and ATC-3 could be clearly distinguished sixteen commercially cultivar rice varieties. Therefore, these markers could be considered highly informative markers. Amplification was carried out with all four 
Table 1. Details of the sixteen cultivars of rice with their parentage, type of variety and maturity days, used in the present study.

\begin{tabular}{lllll}
\hline S.N. & Cultivars & Parentage & $\begin{array}{l}\text { Hybrid/ } \\
\text { Improved Variety }\end{array}$ & $\begin{array}{c}\text { Maturity } \\
\text { (In Days) }\end{array}$ \\
\hline 1 & LALAT & (Obs 677/IR2071//Bikram W1263) & Improved & 135 \\
2 & KRH-2 & Hybrid (IR 58025A/KMR-3R) & Hybrid & $125-130$ \\
3 & COTTONDORA SANNALU & KRISHNAVANI/IR 64 & $120-120$ \\
4 & Improved & $155-160$ \\
5 & RANJEET-2 & (PANKAJ \& MAHSURI) & & $155-155$ \\
6 & IR-64 & (VASISTA/MAHSURI) & Late & $115-120$ \\
7 & PANT-12 & (IR. 5857-33-2-1/IR.2061-465-1-5 5) & Improved & $115-122$ \\
8 & DHANRAN & (GOVIND/UPRM 201-1-1) & Improved & $150-155$ \\
9 & SAVITRI & ------ & & 115 \\
10 & PB-1 & (PANKAJ X JAGANNATH) & Improved & $150-155$ \\
11 & JYOTHI & --------- & Improved & $145-150$ \\
12 & MTU-1031 (Tholakuri) & PTB 10 X IR-8 & Late & Ancient Cultivar \\
13 & KALA NAMAK & MTU 2077 / CR 316- 639 & Improved & $120-125$ \\
14 & VIJETHA (MTU-1001(1) & --------- & & \\
15 & MTU-1001(2) & MTU 5249/MTU 7014 & & \\
16 & RANJEET-1 & ------------- & & \\
\hline
\end{tabular}

Table 2. SSRs Primers used in the present study.

\begin{tabular}{|c|c|c|c|}
\hline S.N. & Primer ID & $\begin{array}{c}\text { Primer Sequence } \\
\end{array}$ & Annealing Temp $\left(\mathrm{A}^{0}\right)$ \\
\hline 1 & СТ 534 & $\begin{array}{l}\text { F ACAGTATTCCGTAGGCACGG } \\
\text { R GCTCCATGAGGGTGGTAGAG }\end{array}$ & 55 \\
\hline 2 & CT 522 & $\begin{array}{l}\text { F GCATGGCCGATGGTAAAG } \\
\text { R TGTATAAAACCACACGGCCA }\end{array}$ & 50 \\
\hline 3 & CT 404 & $\begin{array}{l}\text { F AACGCGAGGACACGTACTTAC } \\
\text { R ACGAGATACGTACGCCTTTG }\end{array}$ & 52 \\
\hline 4 & СТ 360 & $\begin{array}{l}\text { F GGCTTCATCTTTGGCGAC } \\
\text { R CCGGATTCACGAGATAAACTC }\end{array}$ & 50 \\
\hline 5 & СТ 199 & $\begin{array}{l}\text { F TCTCTCCTCTTGTTTGG CTC } \\
\text { R ACACACCAACACGACCACAC }\end{array}$ & 48 \\
\hline 6 & CT 125 & $\begin{array}{l}\text { F CCCATGCGTTTAACTAT TCT } \\
\text { R CGTTCCATCGATCCGTATGG }\end{array}$ & 48 \\
\hline 7 & СТ 519 & $\begin{array}{l}\text { F CAAAAACAGAGCAGATGAC } \\
\text { R CTCAAGATGGACGCCAAGA }\end{array}$ & 50 \\
\hline 8 & CT 106 & $\begin{array}{l}\text { F ATCTTGTCCCTGCAGGTCAT } \\
\text { R GAAACAGAGGCACATTTCATTG }\end{array}$ & 55 \\
\hline 9 & СТ 195 & $\begin{array}{l}\text { F GATCCAGCGTGAGGAACACGT } \\
\text { R AGTCCGACCACAAGGTGCGTTGTC }\end{array}$ & 55 \\
\hline 10 & CT 25 & $\begin{array}{l}\text { F GTACGACTACGAGTGTCACCAA } \\
\text { R GTCTTCGCGATCACRCGC }\end{array}$ & 55 \\
\hline 11 & CT XY1 & $\begin{array}{l}\text { F GTTGCGTCCTACTGCTACTTC } \\
\text { R GATCCGTGTCGATGATTAGC }\end{array}$ & 52 \\
\hline 12 & CT 368 & $\begin{array}{l}\text { F ATCAGCAGCCATGGCAGCGACC } \\
\text { R AGGGGATCATGTGCCGAAGGCC }\end{array}$ & 48 \\
\hline 13 & CT ATC3 & $\begin{array}{l}\text { F ACCCAACTACGATCAGCTCG } \\
\text { R CTCCAGGAACACGCTCTTTC }\end{array}$ & 50 \\
\hline 14 & СТ 353 & $\begin{array}{l}\text { F CAACGTGATCGAGGATAGATC } \\
\text { R GGATTTGCTTACCACAGCTC }\end{array}$ & 48 \\
\hline 15 & GA 562 & $\begin{array}{l}\text { F TAGTGCCGATCGATGTAACG } \\
\text { R CATATGGTTTTGACAAAGCG }\end{array}$ & 50 \\
\hline 16 & GA 397 & $\begin{array}{l}\text { F TGTGAGCCTGAGCAATAACG } \\
\text { R GAAGCGTGTGATATCGCATG }\end{array}$ & 50 \\
\hline 17 & CT 115 & $\begin{array}{l}\text { F CGAGAGAGCCCATAACTACG } \\
\text { R ACAAGACGACGAGGAGGGAC }\end{array}$ & 55 \\
\hline 18 & GA 21 & $\begin{array}{l}\text { F TAGGTTGGCAGACCTTTTCG } \\
\text { R GTCAAGATCATTCTCGTAGCG }\end{array}$ & 48 \\
\hline 19 & GA 3 & $\begin{array}{l}\text { F TTGTCAAGAGGAGGCATCG } \\
\text { R CAGAATGGGAAATGGGTCC }\end{array}$ & 52 \\
\hline 20 & CT 131 & $\begin{array}{l}\text { F GGCTTCATCTTTGGCGAC } \\
\text { R CCGGATTCACGAGATAAACTC }\end{array}$ & 50 \\
\hline
\end{tabular}


Table 3. SRAP primer combination and their sequence.

\begin{tabular}{lllc}
\hline S.N. & Primer Id & Primer sequence (5'to 3') & Bases \\
1 & Me 2 + Em 2 & TGAGTCCAAACCGGAGC + GACTGCGTACGAATTTGC & $17+18$ \\
2 & Me 2 + Em 6 & TGAGTCCAAACCGGAGC + GACTGCGTACGAATTGCA & $17+18$ \\
3 & Me 2 + Em 7 & TGAGTCCAAACCGGAGC + GACTGCGTACGAATTCAA & $17+18$ \\
4 & Me 2 + Em 11 & TGAGTCCAAACCGGAGC + GACTGCGTACGAATTCTA & $17+18$ \\
5 & Me $1+$ Em 1 & TGAGTCCAAACCGGATA + GACTGCGTACGAATTAAT & $17+18$ \\
6 & Me $1+$ Em 3 & TGAGTCCAAACCGGATA + GACTGCGTACGAATTAAT & $17+18$ \\
7 & Me $1+$ Em 7 & TGAGTCCAAACCGGATA + GACTGCGTACGAATTAAT & $17+18$ \\
8 & Me $1+$ Em 9 & TGAGTCCAAACCGGATA + GACTGCGTACGAATTAAT & $17+18$ \\
9 & Me 2 + Em 5 & TGAGTCCAAACCGGAGC + GACTGCGTACGAATTAAT & $17+18$ \\
10 & Me 2 + Em 8 & TGAGTCCAAACCGGAGC + GACTGCGTACGAATTAAT & $17+18$ \\
\hline
\end{tabular}

Table 4. List of the SSRs markers with their unique amplification product. Product size measured in base pair (bp).

\begin{tabular}{llllll}
\hline S. N. & $\begin{array}{l}\text { Primer } \\
\text { Variety } \boldsymbol{V}\end{array}$ & CT-14 & CT-25 & CT XY-1 & AT C -3 \\
\hline 1 & LALAT & 186 & 172 & 260 & 225 \\
2 & KRH-2 & 186 & 136 & 270 & 240 \\
3 & MTU-1010 & 193 & --- & 258 & 235 \\
4 & RANJEET-2 & 179 & --- & 255 & 230 \\
5 & MTU-7029 & 179 & 143 & 250 & 220 \\
6 & IR-64 & 186 & 158 & 225 & 215 \\
7 & PANT-12 & 179 & 143 & 250 & 235 \\
8 & DHANRAN & 165 & 186 & 250 & 225 \\
9 & SAVITRI & 179 & 186 & 235 & 240 \\
10 & PB-1 & 179 & 158 & 225 & 200 \\
11 & JYOTHI & 150 & 179 & 250 & 235 \\
12 & MTU-1031 & 165 & 150 & 240 & 200 \\
13 & KALA NAMAK & 158 & 155 & 275 & 235 \\
14 & MTU-1001 (1) & 158 & 165 & 220 & 230 \\
15 & MTU-1001 (2) & ---- & --- & -- & \\
16 & RANJEET-1 & 150 & 193 & 235 & \\
\hline
\end{tabular}

Table 5. SRAP markers with their unique amplification product. Product size measured in base pair (bp).

\begin{tabular}{|c|c|c|c|c|c|c|c|}
\hline S.N. & Primer Varety & Me2+Em5 & Me2+Em8 & Me1+Em1 & Me1+Em3 & Me1 + Em7 & Me1+Em9 \\
\hline 1 & LALAT & & 1000 & & & & \\
\hline 2 & KRH-2 & 100 & & & & & \\
\hline 3 & MTO-1010 & & & & & & 350 \\
\hline 4 & RANJEET-2 & 800 & 400 & & & & \\
\hline 5 & MTU-7029 & 1100 & & & & & \\
\hline 6 & IR-64 & & & & & 600 & \\
\hline 7 & PANT-12 & & 550 & & & & \\
\hline 8 & DHANRAN & & & & 250 & & \\
\hline 9 & SAVITRI & & & & & & \\
\hline 10 & PB-1 & & 450 & & & & \\
\hline 11 & JYOTHI & & & 980 & & & \\
\hline 12 & MTU-1031 & & & 300,400 & & & \\
\hline 13 & KALA NAMAK & & & & & 930 & 1000 \\
\hline 14 & MTU-1001(1) & & & & 570 & & \\
\hline 15 & MTU-1001(2) & & & 550 & & & \\
\hline 16 & RANJEET-1 & & & 600 & & & \\
\hline
\end{tabular}

polymorphic primers. Scored the bands with respect to molecular marker size is given in the table 4. Similar studies were reported in different rice varieties and hybrid by early workers (Nandakumar et al., 2004; Tamilkumar et al., 2009). Rapid molecular testing techniques for the verification of cultivar identity assume importance in the face of demands for exacting quality in the international trade, the need for assuring homogeneity in planting seed material and the protection of intellectual property rights (Singh et al., 2007). Identification of genotypes based on the presence of unique alleles is of considerable importance as it can help the authorities in detecting any pilferage or mixing in seed lot (Aneja et al., 2012). SRAP markers appear to be much more effective, quicker and less expensive to develop than SSR markers (Ahmad et al., 


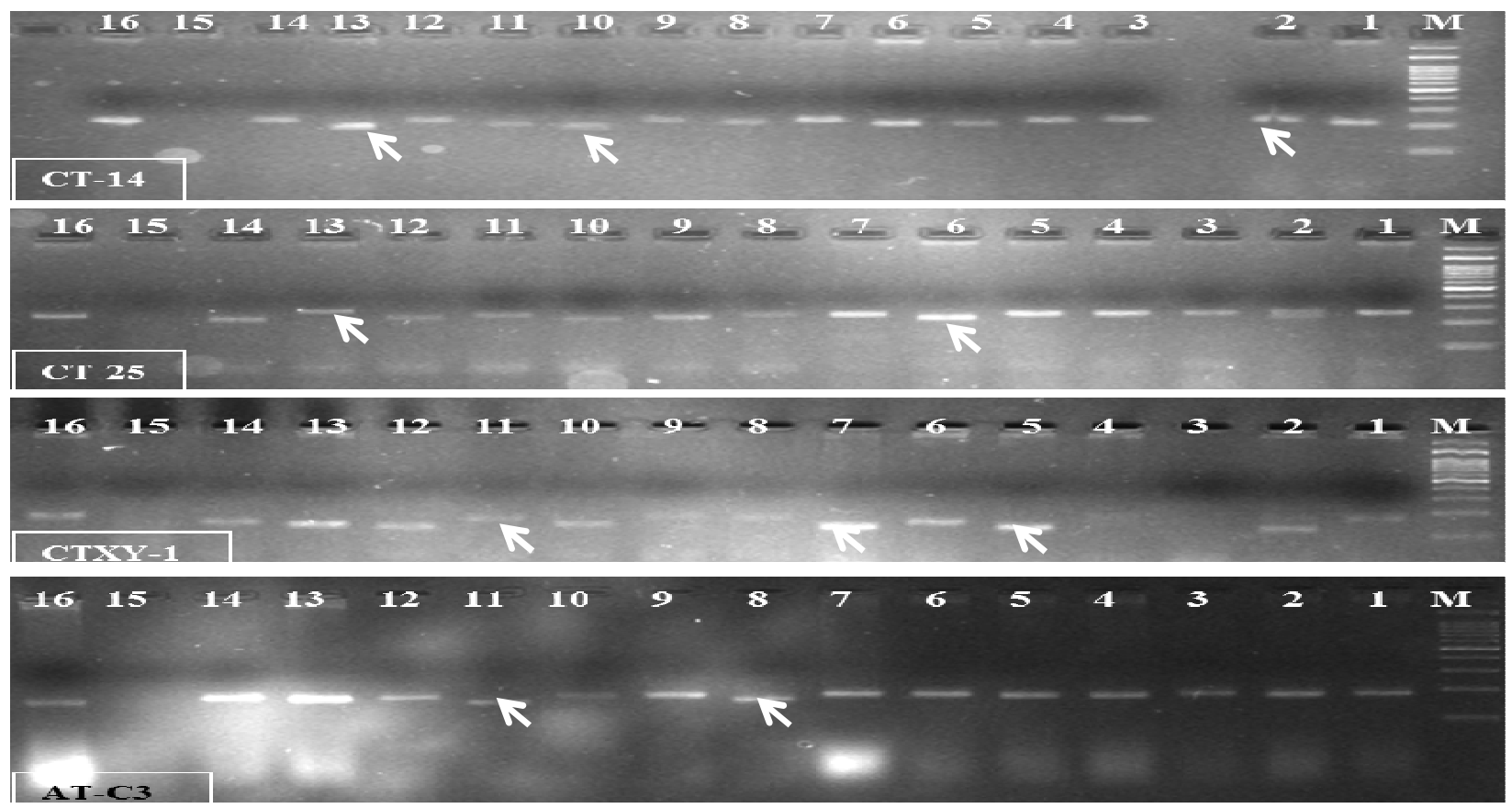

Fig. 1. Agarose gel electrophoresis of a SSR-PCR reaction for primer CT-14, CT-25, CT XY-1 and AT-C3 with Rice DNA samples. Bands were fractionated by electrophoresis on a $3 \%$ agarose gel (1hr, $5 \mathrm{~V} / \mathrm{cm}, 1.0 \mathrm{X}$ Tris-Acetic acid EDTA buffer) and visualized by Ethidium bromide staining. M: $1 \mathrm{~Kb}$ ladder (MBI Fermentas, Lithuania). Lanes: 1.Lalat, 2.KRH-2, 3.MTU1010, 4.Ranjeet-2, 5.MTU-7029, 6.IR-64, 7.Pant-12, 8.Dhanran, 9. Savitri, 10. PB-1, 11. Jyothi, 12. MTU-1031,13. Kala Namak, 14. MTU-1001(1), Mtu-1001(2) and Rajneet-1. Arrows indicate SSR markers unique to particular cultivars.

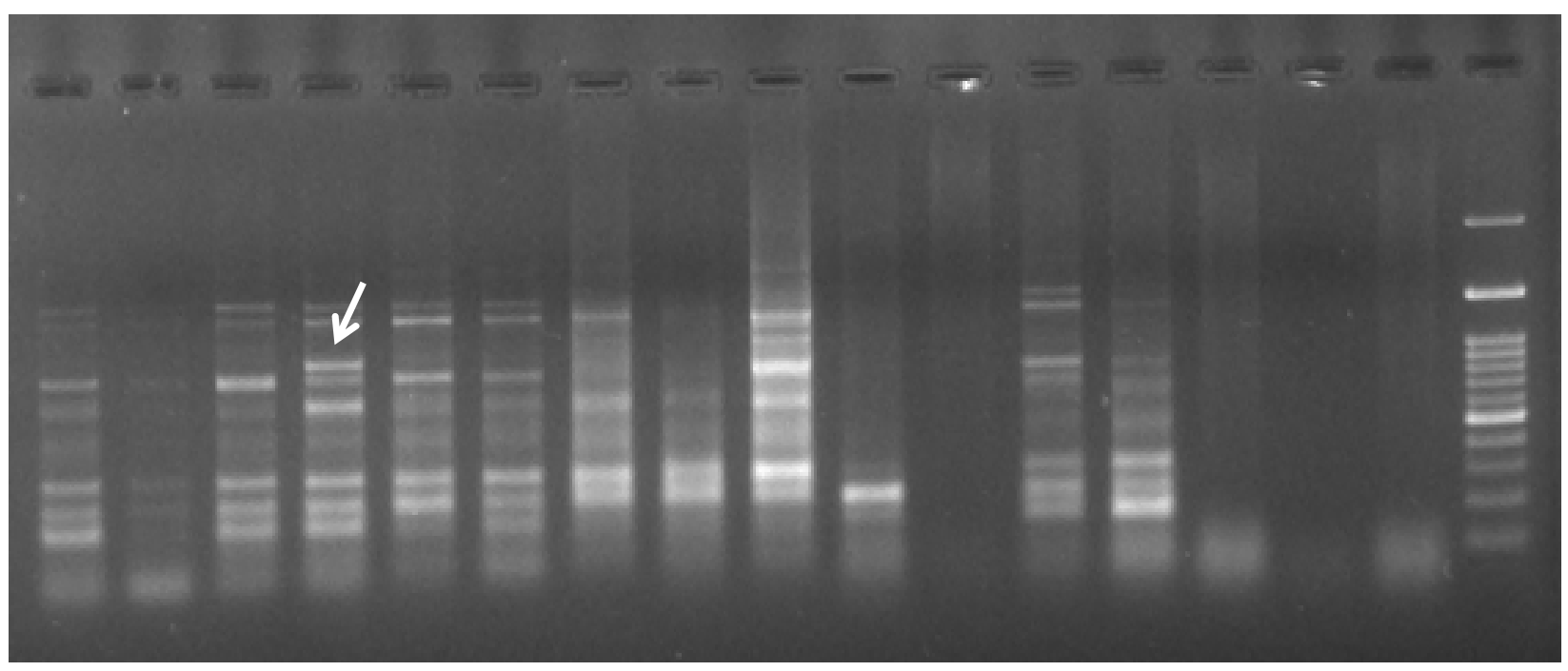

Fig. 2. Sixteen rice cultivars showing the banding pattern with Me2 +Em5 and 8, SRAP marker. Bands were fractionated by electrophoresis on a 3\% agarose gel $(1 \mathrm{hr}, 5 \mathrm{~V} / \mathrm{cm}, 1.0 \mathrm{X}$ Tris-Acetic acid EDTA buffer) and visualized by Ethidium bromide staining. M: $1 \mathrm{~Kb}$ ladder (MBI Fermentas, Lithuania). Arrows indicate SRAP markers unique to particular cultivars.

2004). A set of twenty-two SRAP (Sequence Related Amplified Polymorphism) primer pair were selected for screening. Selection was made from the literature and synthesized them on the basis of their amplification and banding pattern. Out of twenty two SRAP primers six primers gave polymorphic result (Fig. 2). Scored unique bands with respect to their molecular size are given table 5. In addition to single markers, it's better to try with marker combinations (SSR +
SRAP), which were amenable for PCR and capable of distinguishing the varieties. From the table 4 and table 5 such marker combinations can be used. Previous results indicated that SSR and SRAP markers can be used to distinguish the genetically very close cultivers as a complement to traditional pomological studies (Ahmad et al., 2004). According to Sundaram et al. (2008) two informative microsatellite markers, RM164 and RM206 were used for assessment of purity of a 
sample of KRH2 consisting of 400 seeds planted in a grow-out plot during wet season of 2005. Based on single marker and multiplex PCR analysis, RM164 identified eight contaminants and RM206 identified seven as contaminants. Though both the markers individually detected six contaminants, they differed in respect of the seedling numbers detected as contaminant, showing that screening using a single SSR marker may not be always accurate. Previous study revealed that a single polymorphic microsatellite marker might be sufficient for routine analysis of purity of commercial hybrid seed samples (Yashitola et al., 2002). However, the additional information generated through the present study suggests that, in certain cases, the use of single microsatellite marker for purity testing may not be sufficient for accurate detection of impurities. Accurate marker combination and multiplex PCR which is a cost saving strategy, can be carried out simultaneously. Using the marker combination for varietal identification enhanced accuracy. Hence, we propose that analysis using single markers (as proposed by Yashitola et al., 2002 and Nandkumar et al., 2004) may not help in accurate estimation of seed impurities in certain cases, and wherever possible, it is better to deploy more than one marker or through multiplex PCR. A set of morphological descriptors are currently used for varietal identification, description and seed purity assessment. Though widely adopted and practiced, purity assessments based on morphology is often affected by environment, beside the on time and resources. Furthermore, many of the modern high yielding varieties and hybrids are phenotypically less distinct making morphological evaluation more difficult. Molecular markers have been used for genetic characterization of cultivars in rice, wheat, maize, sunflower and tomato (Sundaram et al., 2008; Karkousis et al., 2003; Wang et al., 2002; Zhang et al., 2005; Smith and Register, 1998). The Biochemical and Molecular Techniques Group of the International Union for the Protection of New Varieties of Plants (UPOV) is evaluating different DNA marker parameters prior to its routine use in establishing distinctness, uniformity and stability (DUS) of plant varieties (Bredemeijer et al., 2002; UPOV-BMT, 2002). The present study we have established that selection of molecular marker are informative enough to distinguish all the rice cultivars. We have also identified 'cultivar specific microsatellite profile' for sixteen varieties which could be used for their seed purity estimation at different stages of seed multiplication (Tables 4 and 5).

\section{Conclusions}

With increasing number of public as well as private bred rice hybrids under commercial cultivation, quality control in terms of monitoring seed genetic purity at both parental and hybrid seed production stages is vital for the success of hybrid rice technology. Considering the innate disadvantages of GOT for seed purity analysis, marker based seed purity assay which could be an alternative, is receiving the attention. Replacement of GOT with a marker-based assay demands characterization of the parental lines with a large set of polymorphic markers to identify 'informative' markers. The present study is unique due to the fact that a comprehensive set of four Simple sequence markers and six Sequence Related Amplified Polymorphism markers can be used for distinguishing the commercially using cultivars to develop a marker database consisting of 'informative' SSR and SRAP markers. The utility of these markers in detection of impurities is also clearly demonstrated through cost saving strategies. The marker information developed through this study will be of immense help for rice seed industry to select appropriate marker combinations and assess purity at each stage of seed multiplication.

\section{ACKNOWLEDGEMENTS}

The authors are grateful to National Seed Corporation (NSC), New Delhi for providing seed samples used in the present study. We also thank to the Director, NBPGR, New Delhi for providing facilities.

\section{REFERENCES}

Ahmad, R., Potter, D. and Southwick, S.M. (2004). Genotyping of peach and nectarine cultivars with SSR and SRAP molecular markers. Journal of the American Society for Horticultural Science, 129 (2): 204-210.

Aneja, B., Yadav, N.R., Chawla, V. and Yadav, R.C. (2012). Sequence-related amplified polymorphism (SRAP) molecular marker system and its applications in crop improvement. Molecular breeding, 30 (4): 1635-1648.

Bredemeijer, G. M. M., Cook, R. J., Ganal, M. W., Peeters, R., Issac, P., Noordijk, Y., Rendell, S., Jackson, J., Roder, M. S., Wendehake, K., Dijcks, M., Amelaine, M., Wickaert, V., Bertrand, L. and Vosman, B. (2002). Construction and testing of microsatellite database containing more than 500 tomato varieties. Theor. Appl. Genet., 105:1019-1026.

Chakravarthi, B.K and Naravaneni, R. (2006). SSR marker based DNA fingerprinting and diversity study in rice (Oryza sativa. L). Afr. J. Biotech., 5: 684-688.

Edwards, K., Johnstone, C. and Thompson, C. (1991). A simple and rapid method for the preparation of plant genomic DNA for PCR analysis. Nucleic Acids Research, 19 (6): 1349.

Karkousis, A., Barr, A.R., Chalmers, K.J., Ablett, G,A., Holton, T.A., Henry, R.J., Lim, P. and Langridge, P. (2003). Potential of SSR markers for plant breeding and variety identiWcation in Australian Barley germplasm. Aust. J. Agric Res., 54: 1197-1210.

Li, G. and Quiros, C.F. (2001). Sequence-related amplified polymorphism (SRAP), a new marker system based on a simple PCR reaction: its application to mapping and gene tagging in Brassica. Theor. Appl. Genet., 103 (23): 455-461.

Mc Couch, S.R, Teytelman, L., Xu, Y., Lobos, K.B., Clare, K., Walton, M., Fu, B., Maghirang, R., Li, Z., Xing, Y., Zhang, Q., Kono, Z, Yano, M., Fjellstrom, R., 
Declerck, G., Schneider, D., Cartinhour, S.D., Ware, D. and Stein, L. (2002). Development and Mapping of 2240 New SSR Markers for Rice (Oryza sativa L.). DNA Res., 9:199-207.

Nandakumar, N, Singh A,K., Sharma, R.K., Mohapatra, T., Prabhu, K.V. and Zaman, F.U. (2004). Molecular fingerprinting of hybrids and assessment of genetic purity of hybrid seeds in rice using microsatellite markers. Euphytica, 136: 257-264.

Sambrook, J., and Russell, D.W. (2001). Molecular Cloning: A Laboratory Manual.Vol.1, Cold Spring Harbor Laboratory Press, New York.

Singh, R., Singh, A.K., Sharma, T.R., Singh, A. and Singh, N.K. (2007) Fine mapping of aroma QTLs in basmati rice (Oryza sativa L.) on chromosomes 3, 4 and $8 . J$. Plant Biochem. Biotechnol., 16 (2): 75-82

Smith, J.S.C. and Register, III J.C. (1998). Genetic purity and testing technologies for seed quality: a company perspective. Seed Sci. Res. 8: 285-293.

Sundaram, R..M., B. Naveenkumar, S.K. Biradar, S.M. Balachandran, B. Mishra, M. IlyasAhmed, B.C. Viraktamath, M.S. Ramesha, and N.P. Sarma. (2008). Identification of informative SSR markers capable of distinguishing hybrid rice parental lines and their utilization in seed purity assessment. Euphytica, 163 (2): 215-224.

Tamilkumar, P., Jerlin, R., Senthil, N., Ganesan, K.N., Jeevan, R.J. and Raveendran, M. (2009). Fingerprinting of rice hybrids and their parental lines using microsatellite markers and their utilization in genetic purity assessment of hybrid rice. Research Journal of Seed Science, 2 (3), 4047.

UPOV-BMT (2002) BMT/36/10 Progress Report of the $36^{\text {th }}$
Session of the Technical Committee, the technical working parties and working group on biochemical and molecular techniques and DNA-proWling in particular, Geneva.

Wang, J,. Zhong, G.Y., Chin, E.C.L., J.C. Register III J.C, Riley, R.D., Niebur. W.S. and Smith, J.S.C. (2002). IdentiWcation of parents of F1 hybrids through SSR proWling of maternal and hybrid tissue. Euphytica, 124: $29-34$.

Dan-dan, XUE., GUO Hai-lin,ZHENG Yi-qi,CHEN Xuan, and LIU Jian-xiu. (2009). Hybrid identification of progenies of Zoysia crosses by SRAP marker[J]; Acta Prataculturae Sinica;-01.

Yashitola, J., Sundaram, R.M., Biradar, S.K., Thirumurugan, .T, Vishnupriya, M.R., Rajeshwari, R., Viraktamath, B.C., Sarma, N.P. and Sonti, R.V. (2004). A sequence speciWc PCR marker for distinguishing rice lines on the basis of wild abortive cytoplasm from their cognate maintainer lines. Crop Sci., 44: 920-924.

Yashitola, J., Thirumurugan, T., Sundaram, R.M., Naseerullah, M.K., Ramesha, M.S., Sarma, N,P., Sonti, R.V. (2002). Assessment of purity of rice hybrids using microsatellite and STS markers. Crop Science, 42: 1369-1373

ZHANG, Jing,, HUANG, Lin-kai., ZHAO, Bing-yu., ZHANG, Xin-quan., YAN, Hai-dong. and JIANG, Xiao-yang. (2012). Comparison of SRAP and SSR markers for hybrid identification of switchgrass(Panicum virgatum). Acta Prataculturae Sinica, 2012-05

Zhang, L.S., Clerc, V.L., Li, S. and Zhang, D. (2005). Establishment of an effective set of simple sequence repeat markers for sunflower variety identification and diversity assessment. Euphytica, 83:66-72. 